\title{
AGENCY, STEWARDSHIP AND THE UNIVERSAL-FAMILY FIRM:
}

\section{A QUALITATIVE HISTORICAL ANALYSIS}

\begin{abstract}
This paper introduces the idea of a non-kinship-based Universal-family firm, an organizational form we developed based on interpreting historical writings in their socio-economic context. We analyzed Luke's gospel with an eye toward drawing implications for the stewardship-agency debate in the contemporary family business literature. Our paper makes contributions at two important levels. In addition to introducing and developing theory about the Universal-family firms, we also contribute to the methodological toolkit of family business scholars by providing a template for using historical documents to challenge, enhance and develop theory.
\end{abstract}

\section{KEYWORDS}

Family Business, Stewardship, Agency, Value Creation/Capture, Gospel of Luke

Sometimes our dominant conceptual frameworks and ways of seeing unintentionally serve to become ways of not seeing (Poggi, 1965), and we become encaptured in a sociallyconstructed reality that we have inherited and that we unwittingly perpetuate (Berger \& Luckmann, 1967). Although such frameworks are necessary for us to develop richer understanding and theory, it is also helpful to step outside of established conceptual boxes and look at phenomena from new perspectives. Among scholars, such stepping outside is typically facilitated by observing empirical phenomena that do not seem to fit within existing theories, as is happening today in the world of physics where findings consistent with quantum mechanics (e.g., with regard to wave-particle duality) are upending long-held assumptions consistent with the Newtonian classical world (e.g., Kim et al., 2000).

This paper represents one small such an instance of stepping outside, and describes its implications for family business generally, and for the agency-stewardship debate within the family business literature specifically. In particular, this paper will introduce and develop the concept we call the Universal-family firm, which is an organizational form that we believe exists in the empirical world, is timely for issues facing contemporary scholars and 
practitioners, and is especially relevant for the agency-stewardship debate within family business research. As we shall see, the Universal-family firm describes a type of family firm that — paradoxically—is not based on a kinship ties. What do family firms look like if their definition is not based on blood-lines?

Our review of the literature suggests that, whilst the long history of family firms may implicitly lead scholars to see this kinship-based organizational form as somehow timeless, wholesome, and noble, nevertheless this organizational form has also been long-criticized, and attempts have been made to address its shortcomings. We then introduce an overarching two-dimensional framework related to the agency-stewardship debate in family business. Next, we briefly look at Aristotle's writings relevant to agency and stewardship in the family firm, which provide a context for our analysis of the Gospel of Luke. We subsequently present the method and context for our analysis. This includes setting out the historical understanding of family firm systems, norms and structures in the world of the GraecoRoman Mediterranean, focusing on the primary goods and services producing organization of the day, the oikos — or what today might be called a family-in-business. We then examine an especially relevant biblical text—-the so-called "Central Section” of Luke's Gospel—to explore what it says about the family-in-business, paying special attention to its contribution for understanding of the universal family-in-business in the light of modern discussion around stewardship and agency. In our final Discussion we provide historical and contemporary examples of Universal-family firms, discuss implications for agency and stewardship theory, and present the key components for building theory related to the Universal-family firm.

\section{LITERATURE REVIEW}

For most of the history of humankind, the oikos — a forerunner of today's family firm — was the primary form of a goods and services producing organization. Aristotle provides perhaps the most influential early analysis of the oikos, which continued to change 
and evolve through Roman times, the Middle Ages, and through to the present. In particular there has been an on-going debate concerning issues related to what contemporary family firm scholars would call stewardship (the potentially positive characteristics of family firms associated with their more communal, long-term and altruistic nature) versus agency (the potentially exploitive and nepotistic character of family firms). Madison et al's review (2016, 15), for example, contrasts inter alia agency theory's economic behavioral assumptions with the more humanistic stewardship assumptions; agency's governance emphasis on incentives and monitoring with stewardship's trust and empowerment; and the opportunistic and freeriding behaviors of agency, with the other-serving, pro-organizational behaviors of stewardship $(2016,15)$.

Agency and stewardship theory. Agency theory starts with the assumption that people are self-interested and prone to acting opportunistically (e.g., Barney \& Hesterly, 1999). In particular, agency theory tends to focus on the (contractual) relationship between a business's owners (principals) and its managers (agents) (Jensen \& Meckling, 1976). The agency literature on non-family firms focuses on designing principal-agent contracts such that the incentives for a firm's managers coincide with the outcomes sought by its owners. In this regard, family firms are thought to enjoy a relative advantage because owners and managers are often one-and-the-same, which automatically aligns manager-owner interests and thus reduces family firms' agency-based risks and costs (e.g., the costs of designing and monitoring principal-agent contracts) (e.g., Anderson \& Reeb, 2003).

Of course, this is not to say that agency theory is irrelevant for family firms. Typically, when (behavioral) agency theory is applied to family firms, it focuses on how managers in family firms may sacrifice their firm's economic performance in order to preserve the socioemotional wealth that their family derives from the business (Madison et al, 2016; Gomez-Mejia et al., 2007; Miller et al., 2014; Wiseman \& Gomez-Mejia, 1998). For example, 
consider firms that have multiple owners, but where one family has ownership control. Such a family can exploit smaller owners by entrenching its family members in key positions and appropriating resources from the business to pursue benefits for its family members (Le Breton-Miller \& Miller, 2009, p. 1172). Such agentic actions may serve the interests of the dominant family at the expense of the long-term overall performance of the firm (cf. Bertrand \& Schoar, 2006;

Demsetz, 1983; Morck \& Yeung, 2003; Morck et al., 2005; Shleifer \& Vishny, 1997).

Stewardship theory relaxes the assumptions of economic self-interest and opportunism, and suggests that people are also motivated to serve others and to be generous and altruistic (Davis, Schoorman, \& Donaldson, 1997; Donaldson, 1990; Le Breton-Miller \& Miller, 2009; Le Breton-Miller, Miller \& Lester, 2011). Scholars tend to argue that stewardship practices are more likely to be evident in family firms than in non-family firms (see, for example, Aronoff \& Ward, 1995; Wade-Benzoni, 2002; Corbetta \& Salvato, 2004; Lubatkin, Durand, \& Ling, 2007). In today's marketplace, where long-term social and ecological considerations are increasingly valued, these aspects inherent in family firms seem to give them a relative advantage over non-family firms (Eddleston et al., 2012, pp. 249-250). At least five factors explain why family firms place relatively high emphasis on stewardship:

1) interpersonal relationships within family firms often have characteristics associated with stewardship, including stability, significant interaction and interdependence, and a shared social network (Le Breton-Miller et al, 2011; Bourdieu, 1986; Nahapiet \& Ghoshal, 1998);

2) family firms tend to place greater value on the firm's relational and socioemotional value and identity (hallmarks of stewardship) than non-kinship firms (Le BretonMiller, 2009; Gómez-Mejía et al., 2007);

3) owners of a family firm tend to have a longer term commitment to their firm (e.g., in terms of jobs and income for future generations) than owners of non-kinship firms (thus, for example, family firms are more willing to make a short-term sacrifice if it enhances the firm's long-term well-being; Le Breton-Miller et al, 2011);

4) owners of a family firm are more likely to perceive their personal reputations to be enhanced by their firm engaging in stewardship activities than are owners of non- 
kinship firm (e.g., Sirmon \& Hitt, 2003); and

5) family firms are more likely to be inherently moral, due to the shared identification of their members with core cultural values (Blodgett et al., 2011, p. 35; Haugh \& McKee, 2003, p. 141; Payne et al, 2011; Vallejo 2008, p. 271), their enhanced socioemotional wealth (Hauswald \& Hack, 2013, p. 361), and often shared religious convictions (James, 2006; Le Breton-Miller, 2009, p. 1182; Lungeanu \& Ward, 2012, p. 409; Vallejo, 2008, p. 263).

\section{Value creation vs value capture: Towards an organizational typology}

The distinction between value capture versus value creation - which is becoming key in the strategy literature (e.g., Santos, 2012)—is helpful for enriching our understanding of differences between agency and stewardship. Value creation is measured at a societal level of analysis, and is evident "when the aggregate utility of society's members increases after accounting for the opportunity cost of all the resources used in that activity" (Santos, 2012, p. 337). For example, value creation occurs when a firm uses resources in a new way that provides more benefit for more people than had been the case without the firm. To remain viable in the long-term, all firms need to create value at the societal level. In contrast, value capture occurs at a smaller unit of analysis (e.g., a firm, agents within a firm), and is evident "when a focal actor is able to appropriate a portion of the value created by the activity [of a firm] after accounting for the cost of resources that he/she[/the firm] mobilized" (Santos, 2012, p. 337). At the firm level, profit is a common measure of value capture. Value capture can also take place within a firm, and is evident in differing proportions of value appropriated, for example, by men versus women, executives versus front-line workers, engineers versus marketers, and, in family firms, family members versus non-family members. Some form of value creation and value capture must be evident in all viable firms; though, as depicted along the horizontal dimension in Figure 1, firms may place differing emphases on these two. Along the vertical dimension of Figure 1 we see that organizations may, or may not be, kinshipbased firms. Of course, as with other typologies, most firms are between the two extremes of value capture and value creation, and there are many shades of grey between being wholly 
kinship-based versus non-kinship-based firms.

- Insert figure 1 about here -

In terms of the four quadrants in Figure 1, "Conventional firms" refer to (non-family) firms that seek to maximize organizational profits, and assume that actors are motivated and will take advantage of opportunities to enhance their own financial self-interests (consistent with agency theory). This quadrant encompasses much of the mainstream business literature. For example, the strategy literature shows how firms can and should seek to take advantage of their relative advantages vis a vis competitors, suppliers and customers (e.g., Porter's [1980] 5 forces) and how, at a societal level, firms should take advantage of externalities such as seeking to pay lower taxes, reduce costs for employee benefits, minimize pollution clean-up expenses, and so on. Within the firm, precautions need to be taken to ensure that members will act in the interests of owners, rather than in their self-interests.

"Agentic family firms" are those where a focal kinship family seeks to maximize value capture for itself (as opposed to for the overall firm and/or other stakeholders). In a sense, agentic families seek not only to capture the value creation of the firm in the larger marketplace (akin to conventional firms), but also seek to capture a disproportionate share of the value within the firm. This can be dysfunctional in the long-term for a variety of reasons: 1) it has a negative effect on the loyalty and the work effort of non-family members; 2) it distracts attention away from ensuring long-term value creation in society; and 3) it siphons resources away from investments to enhance the long-term financial performance of the firm. The third quadrant, "Stewardship family firms," are those who focus on value creation beyond the family to include all the firm's stakeholders. While this may limit the opportunity for the family to maximize its value capture in the short-term (versus the Agentic family firm), the typical implicit assumption is that this will enhance the firm's value capture in the long-term. This Stewardship approach to long-term value creation places greater emphasis on 
non-financial measures of value than is evident in Agentic family firms. Family firms in the Stewardship quadrant value their reputation and their relationships with key stakeholders. Thus, these firms will relax the short-term actions such as those associated with Porter's (1980) five forces, and will proactively internalize some of the externalities associated with their activities (e.g., voluntarily offer benefits to their employees). Again, this should bode well for improving the long-term value-capture-ability for Stewardship family firms in a marketplace that is placing greater emphasis on addressing socio-environmental problems. However, note that even the Stewardship family firm is seeking to benefit primarily the kinship family and its related stakeholders, perhaps sometimes at the expense of other (needier) societal groups.

The fourth quadrant, "Universal-family firms," represents an organizational ideal-type that emphasizes aspects of stewardship and value creation that have been associated with family firms, while avoiding agentic and exploitive tendencies that have been associated with formal kinship ties of blood or law. It is a universal family firm in that, even though its members are not related to each other by blood, it is characterized by having other-focused, inclusive, long- term relational qualities typically associated with family firms, plus an emphasis on socio-emotional wealth that goes beyond the organization's stakeholders. Such firms are increasingly hinted at, discussed and called for in the literature, but not often examined empirically. Notable exceptions include research on social enterprises, Benefit Corporations, the fourth sector, hybrid organizations, humanistic management, and Corporate Social Responsibility (e.g., André, 2012; Battiliana et al., 2012; Davis, 2013; Gaffney, 2012; Von Kimakowitz et al., 2010). However, as others have noted, this type may be difficult to sustain because of market forces and institutional norms (e.g., Santos, 2012). For example, Corporate Social Responsibility often gets co-opted by the value capture paradigm (Margolis \& Walsh, 2003). Such co-optation leaves unharvested a vast field of value creation 
opportunities for potential Universal-family firms (e.g., the kinds of opportunities that create value for marginalized members of society but do not maximize a firm's ability to capture financial value). For example, Bill Gates describes why millions of children die because they lack medicine that costs less than one dollar per person: "The answer is simple, and harsh. The market did not reward the saving the lives of these children" (Gates, 2007: not paginated). Universal-family firms are more likely to seek opportunities to serve such needs. As will become evident in our findings, Universal-family firms are of particular importance in the Gospel of Luke.

\section{History and the family firm}

The appeal of family firms is often set out in terms which laud their more natural traditional nature; an idealistic past embodied in business form (e.g., Mitchell et al., 2011, p. 243). Perhaps paradoxically, contemporary family business scholars often forget that variations of family business have been the dominant form of goods and services producing organizations for most of the history of humankind. Yet if their place in the historical tradition is part of what makes family firms so special, resonant, and appealing-individually and collectively - then it is also relevant to engage with historical readings of the family-inbusiness. This is echoed in calls for scholars to pay more nuanced attention to the inherent heterogeneity of family firms across contexts (Sharma et al., 2012, p. 10; Gupta \& Levenburg, 2010, p. 166; James et al, 2012, pp. 87-88). Indeed, as Andrea Colli has argued:

"As the notion of the family itself has evolved over time, family values and goalsincluding the economic ones - have also been subject to a process of transformation. Here, too, historical research based on primary sources can help highlight not only the role of family values in driving entrepreneurial choices but also the transformations in ideological frameworks caused by changes in the prevailing culture" $(2012$, p. 245).

In general terms, we hope to contribute to what might be called a History of Family Firm Analysis by exploring some significant, traditional origins of the family-in-business heritage. We have chosen biblical writings because of the influence of the Christian heritage 
on (especially Western) society. With about one-third of the world claiming to adhere to it, Christianity is the largest religion in the world, and Christian writings have played an important role in the scholarly development of modern ideas about capitalism and business, as illustrated by the enormous influence of Max Weber's The Protestant Ethic and the Spirit of Capitalism. As Drakopoulou Dodd and Gotsis (2009, p. 101) have argued: "Christianity and enterprise have been linked so repeatedly, in such a variety of ways, that a study of their very earliest relationship is a worthwhile exercise in its own right."

Our study explores narratives about management, organization, and family in the Gospel of Luke, which was likely written in about 80-90 AD (about 50 years after Jesus' crucifixion). The author we refer to as Luke is recognized as the most cosmopolitan and educated of the four gospel authors, writing in the lingua franca of the day, Koine Greek, whilst also clearly echoing the Hebrew Old Testament, and Ancient Greek philosophical and historical writings. Luke's Gospel refers to over 50 goods and services producing organizations (oikoi), and it contains the majority of mentions of management, organization, wealth, and stewardship found in all four Gospels (see Dyck, 2013, which we draw from and build upon extensively in this paper). More specifically, our examination will focus on what scholars call the Central Section of Gospel (Luke 9:51-19:40). Also known as The Journey Narrative, Luke sets the Central Section in the context of Jesus and his disciples making the transition from their preaching in Galilee, to the climactic events to transpire in Jerusalem. More importantly, the section has about 75 percent of the mentions and discourse within Luke's Gospel that relate to management and family business - and what it says about the tension between stewardship versus agency.

\section{Relevant Ideas in the Historical Literature: Building on the Shoulders of Aristotle}

Before we turn our focus to the Gospel of Luke, it is appropriate to briefly situate it within its context. If Luke had started his Gospel with a literature review summarizing key 
theory in the field of oikos studies, it would have included issues similar to those being discussed in the contemporary literature regarding stewardship and agency theory, and value capture and value creation. Perhaps most notable is Aristotle, whose writings provide a basis for developing the Stewardship family quadrant. This is evident in Aristotle's description of two approaches to chrematistics, a term that essentially refers to the management of money in goods and services producing organizations. Aristotle suggests that "natural chrematistics" (“sustenance economics," Dyck \& Neubert, 2010) emphasizes the use value of money to facilitate overall value creation for the community (everyone wins). He contrasts this with "unnatural chrematistics," ("acquisitive economics") which emphasizes the exchange value of money and treats it as a rent-seeking commodity, so that money becomes a measure of value capture, and thereby deflects attention away from value creation. Aristotle lamented that some people were being led to believe that increasing financial wealth was the purpose of managing goods and services producing organizations, and as a result

"the whole idea of their lives is that they ought either to increase their money without limit, or at any rate not to lose it. The origin of this disposition in men [sic?] is that they are intent upon living only, and not upon living well; and, as their desires are unlimited they also desire that the means of gratifying them should be without limit" (Aristotle, Politics: Book I, IX; emphasis added here).

Karl Polanyi (1944, pp. 53-54; see Dierksmeier \& Pirson, 2009) has suggested that Aristotle's distinction regarding these two approaches to managing money within goods and services producing organizations "was probably the most prophetic pointer ever made in the realm of the social sciences" and "certainly still the best analysis of the subject we possess."

\section{METHODOLOGY}

Our methodological approach—which includes a combination of biblical theology, linguistic analysis, redaction criticism, and socio-economic history-is consistent with and builds upon the work of other historians, economists and social scientists who seek to interpret the biblical texts in their historical socio-economic and religious context (e.g., Dodd 
\& Gotsis, 2009; Dyck, 2013; Elliott, 1991; Hanson \& Oakman, 1998; Kloppenborg, 2008; Malina \& Rohrbaugh, 2003; Moxnes, 1988). Consistent with biblical scholarship, we engage in detailed textual analyses and draw on knowledge of the ancient languages implicated in the specific text (such as New Testament Greek, Hebrew and Aramaic), as well as of rhetorical structures of the day, of the nature of metaphor, analogy and other devices. Evidence from the archaeological record is additionally drawn upon, where relevant (e.g., Reed, 2007). Also deployed are comparisons with related contemporaneous works, including other sections of the New Testament, for example. Earlier potential influences on the text in question are also considered, especially from the Judaic tradition, other Levantine religions, and Greek philosophy (we have presented Aristotle's work as an example of such influences).

This background knowledge is essential for exegesis, namely the interpretation of (Luke's) text in its historical context. However even when exegesis work is done properly, interpreters must be conscious of eisgesis, which refers to bringing their own presuppositions and biases into a text. A particular tendency - and, indeed, an understandable one - is for a text's words to be read as though they had been written in the here and now, to strip them of their historical, cultural and geographic context, and to impose the reader's instead.

Our study involved detailed analysis of Luke's Central Section (Luke 9:51-19:40), with both co-authors separately carrying out original (re-)examinations of this text and highlighting passages of special relevance for our main interest in family, management, and the related topics of socio-economic ethics, assets, and authority. Special attention was paid to the practices enacted and depicted within this narrative, and to the importance of the context within which the parables, stories, and other discourse, were originally set. To reduce further the potential dangers of eisgesis associated with specific biblical translations, one author worked from the New Testament Greek text of the Central Sections (considering all extant 
variants), and both explored multiple English language translations, as well as detailed commentaries of the key passages discussed below (e.g., Marshall, 1978).

After relevant passages had been identified and studied in detail, our analyses were compared, contrasted, and debated. We also continued to draw iteratively, throughout the process, on theological analysis, and much detailed reading of extant Lucan scholarship among the social sciences. This hermeneutic and historical scholarship led to a critical reading, an exegesis, of the Central Section's family-in-management discourse. The novelty in our study stems from the identification and collation of family business related excerpts in this text, and their analysis as a related body of work.

\section{'Oikos' - The Historical Family-in-Business}

A historical understanding of the Greek word oikos - a term that of its very essence combines both business and family_represents an important key for unlocking what Luke and other writers of his temporal context say about family-based goods and services producing organizations. The word oikos is usually translated into English as "house," but this invites two eisgetical problems in interpretation because today the term house is typically associated with (1) one's nuclear family (e.g., typically parent and child) and (2) being a consumptive social unit (e.g., people earn their livelihoods by working outside of the house). Both these contemporary understandings of house contrast strongly with the understanding of oikos throughout most of the history of humankind.

First, consistent with contemporary understandings, at the center of the classic oikos are two parents and their children. However, the oikos also included its slaves, any free servants, their children, other dependent kin, and its physical assets. Indeed, even though the emotional ties of the nuclear family were clearly of great importance in ancient times (Saller \& Shaw, 1984), at that time there was no term, no word or concept which conveyed what we mean by family, and especially what today is meant by the nuclear family (Rawson, 2011, p. 
3). Second, the oikos was the primary goods and services producing organizational form through most of the history of humankind. Any oikos that did not produce goods and services was not truly an oikos (e.g., Nagle, 2006).

With regard to the modern discussion around issues of stewardship and agency, it is key to understand historical norms around the idea of honor, and how it can be achieved via financial wealth and patron-client relations. Honor was akin to social capital, which was expressed mainly through kinship (belonging), politics (power), and religion (theological virtue) (Drakopoulou Dodd \& Gotsis, 2009, p. 102; Esler, 2000, p. 13). Patron-client relationships refer to relationships between two oikoi of different status, where one oikos (the client) has a duty to give honor to a second oikos (the patron) which has provided the client with some service (e.g., loaned money, granted a political favor). Actions like borrowing money were not one-time transactions; rather, they established long-term (cross-generational) patron-client relationships between organizations. Wealth, honor and status were considered a property of the oikos, rather than of individuals. Indeed, it has been argued that personal identity was essentially tied-up in a social ego, in being part of the wider oikos (Bowen, 1978, p. 73; Malina \& Neyrey, 1991).

The classic Greeks promoted an understanding of oikos that could be considered a forerunner to the Stewardship family firms ideal-type (see Figure 1). In Ancient Greece to be a patron meant to be a benefactor in the best sense of the term (akin to Old Testament ideas about charity and shalom), with a primary duty to improve the lot of the marginalized, or of the public good (value creation). It was an open-handed affair, and had little to do with 'banking' favors and building dependencies. This is consistent with Aristotle's promotion of sustenance economics, where a natural engagement with money and business was one where the profit motive came far down the list of objectives, and which involved some form of productive economic activity. Wealth enabled the rich to carry out their civic duties, including 
funding public works and charity, although it could also distract from pursuing the good life (Aristotle, 2006; see also Galbraith, 1987, p. 15, Karayiannis, 1992, p. 71). Moreover, the then-prevalent zero-sum game worldview of resources meant that (agentic) striving to become richer must always be at someone else's expense, thus widening the gap between rich and poor, and thus seen to be immoral (Drakopoulou Dodd \& Gotsis, 2009).

In contrast, the views of oikos that dominated during the Roman empire could be considered forerunners of the Agentic family firm ideal-type (see Figure 1). For the Romans, a key purpose of the oikos was to build up long-lasting honor for itself characterized by an emphasis on acquisitive economics where the rationale for creating and sustaining socioeconomic patron-client bonds was to enhance benefits to ones' own oikos (value capture). By the first century honor, status and wealth had become increasingly intertwined (e.g., Neyrey \& Stewart, 2008), and wealth generation had lost many of its negative connotations among the elite. To act honorably was synonymous with bringing wealth and status to one's oikos. Indeed, any oikos member who provided some sort of benefit to other oikoi was duty-bound to ensure that these other oikoi would become clients to the member's oikos. Increasing financial wealth, and using it to develop self-serving patron-client relationships, had become a primary way to enhance the honor of an oikos. This was especially true in larger centers of the Roman empire.

These changes were playing out in the local socio-cultural context of Luke's Gospel. As the wealthy were becoming richer in first-century Palestine, they increasingly followed the pattern of urbanization evident in the rest of the Roman empire, becoming absentee landlords, and leaving the administration of their country estates to managers, who became key members of the oikos (Aristotle Politics; Baergen, 2006, p. 33; Goodrich, 2010, p. 82). Indeed, as much as eight percent of the population in the first century may have been (non-kin, usually slave) managers, often acting to support elite family estates. Also important within the economy 
were the smaller oikoi of artisans, farmers, fishermen, and traders, whose domestic and productive lives were also inextricably joined together into what was sometimes called the oikos of the Emperor. In first-century Palestine, however, about ten percent of the population did not have the safety net of belonging to an oikos, often because of bankruptcy (e.g., due to increasing Roman taxes) or because of illness (e.g., they were outcasts because they were considered to be religiously impure) (Dyck, 2013, p. 36).

Having set the historical socio-economic context for Luke, we will now explain and discuss what Luke's Central Section tells us about the family-in-business, and consider how his writings may shed light on modern analysis of stewardship and agency.

\section{ANALYSIS AND FINDINGS}

By way of overview, our findings will show that Luke's Central Section has many counter-cultural implications with regard to the dominant first-century understanding of oikos. We will look at each of the following in turn. First, in perhaps his most radical statementsaimed at the intermediate adult generation and especially Jesus' disciples and followersLuke calls for adult children to separate themselves from the resources and social relationships of their kinship family oikos. In terms of Figure 1, these passages critique kinship-based firms (i.e., the lower two quadrants). Second, Luke critiques agentic norms and behaviors within the conventional first-century oikos. In terms of Figure 1, these passages criticize firms who focus on value capture (i.e., the two quadrants on the left-hand side). Third, Luke presents a fairly well-developed analogical description of Jesus' new exemplary oikos, which he often describes using language associated with the kingdom of God (i.e., which refers to the peculiar managerial character associated with an altruistic God), incorporating managerial, inheritance and power-transfer references. In particular, Luke promotes a Universal-family form of oikos and describes its hallmark characteristics which include: welcoming the marginalized, refusing to lord it over other members or other oikoi, 
servant leadership norms, and embracing salvific organizational structures and systems. In terms of Figure 1, these are hallmarks of Universal-family firms depicted in the fourth quadrant. We will present each theme in turn.

\section{Disbanding the Kinship-Based Organizational Form (Oikos)}

Luke's Central Section takes a radical stance-from the perspective of classic Greeks and from the first and a twenty-first century — on the matter of family roles in transgenerational goods and services producing organizations. Destro and Pesce's (2003, p. 225) study of family and households in Luke's Gospel concludes that followers of Jesus were called to leave the conventional kinship-based oikos of their parents, just as Jesus and his disciples had done. This is an important point for our study, given the position of such adult successors-in-waiting within the family-in-business (Aristotle). In each of the five passages in the Central Section which address relationships between parents and their adult children, Luke describes Jesus directly challenging conventional views of oikos and encouraging adult children to leave their kinship oikos behind. For example, a passage near the beginning of the Central Section (Luke 9:57-62) describes Jesus telling three small stories, all of which are about the need for his followers to leave home and family — their oikos — behind. This passage begins with Jesus suggesting that he does not have a traditional oikos: 'the foxes have holes, and the birds of the sky have nests, but the Son of Man has no place to lay his head.' Without his own oikos, Jesus cannot serve as a traditional patron for follower-clients, so a traditional socio-cultural norm is immediately challenged. In the second and third stories, Jesus is shown making quite extreme demands of his would-be followers, refusing them even a farewell to their biological families. One young man is told to leave his father unburied, which was more unthinkable in the first century than it is today. Given the position of these little vignettes at the very opening of the Central Section, it seems clear that Luke is establishing the 
importance of stepping away from the traditional bonds of oikos, and of the familial ties, wealth and honor codes associated with these structures.

Still more graphic insistence on this theme can be found in three further passages, later in the Central Section, which make clear that for Luke's Jesus, the middle generation should forsake their traditional kinship family oikos (Luke 12:51-53; 14:26; 18:29b-30)1:

"Do you think that I have come to bring peace to the earth? No, I tell you, but rather division! From now on five in one household will be divided, three against two and two against three; they will be divided: father against son and son against father, mother against daughter and daughter against mother, mother-in-law against her daughter-in-law and daughter-in-law against mother-in-law.” (Luke 12:51-53)

"Whoever comes to me and does not hate [that is, separate themselves from] father and mother, wife and children, brothers and sisters, yes, and even life itself, cannot be my disciple." (Luke 14:26)

"Truly I tell you, there is no one who has left house or wife or brothers or parents or children, for the sake of the kingdom of God, who will not get back very much more in this age, and in the age to come eternal life." (Luke 18:29b-30)

These passages would seem very harsh and offensive if they were not understood as part of Luke's recurring theme that challenges conventional family oikos structures and systems. The verses are not an attack on the people that comprise one's kinship family, but rather they are a part of encouraging listeners to consider non-kinship structures and systems for providing goods and services, especially in light of the cultic oikos of the new kingdom of God.

Jesus himself models this by exiting from his own birth oikos; Jesus does not take over as the head of his kinship family's oikos, but instead becomes an itinerant preacher. Moreover, Jesus distances himself further from his biological family when, in response to a woman who shouts out blessings on his birth mother, Jesus says: "Blessed rather are those who hear the word of God and obey it" (Luke 11:27-28). Earlier, in a similar situation, Jesus points to a universal family when he says: "My mother and my brothers are those who hear

\footnotetext{
${ }^{1}$ Note that all biblical quotes in this paper are taken from the New Revised Standard Version (e.g., Metzger \& Murphy, 1991).
} 
the word of God and do it" (Luke 8:21). Again, the cultic universal family oikos is given precedence over a traditional kinship family-in-business understanding.

In terms of Figure 1, this theme seems to suggest that there is no inherent value in the conventional kinship-based family firm per se (i.e., the lower two quadrants). As will be evident in the next theme, this is especially true regarding the value-capturing nature of conventional kinship-based oikos forms.

\section{Denunciating a Conventional Value-Capture-Focused Organizational Form (Oikos)}

The Central Section is filled with passages that identify shortcomings of conventional value-capturing oikos practices. Most of these have some variation of the theme: a primary focus on the financial well-being of your kinship oikos is hollow, disrupts relationships among society's oikoi, and may contribute to the poverty and marginalization of others, especially those who themselves have been excluded from membership in a kinship oikos. For example, when Jesus is asked to intervene to ensure that a grown child receive his proper (kinship) oikos inheritance (Luke 12:13), he responds by telling the parable of the Rich Fool (Luke 12:16-17), which describes a self-congratulatory wealthy landowner who has a good harvest and decides he will build even more barns to store his assets. That same night he dies and God calls him a fool, asking whom all these goods belong to now. Echoing Aristotle's views on living only versus living well, this parable teaches listeners not to be concerned by maximizing how much financial wealth they will get from their oikos — “for one's life does not consist in the abundance of possessions"- - but rather to be concerned about living a genuinely good life (see also Luke 17:26-31).

Perhaps the most famous passage on this topic is the Parable of the ten pounds (Luke 19:11-26), which describes a nobleman asking three of his managers to use his riches to make more money. One manager refuses to do so and is punished, while two managers double their master's wealth and are rewarded. Whereas the very earliest interpretations of this passage 
recognize the third manager as the "hero" (he refused to use money to widen the gap between rich and poor), many contemporary interpretations suggest the managers who doubled their master's wealth are the ones to emulate (for a more detailed analysis of this contested parable, see Dyck, 2013, and Dyck, Starke, \& Dueck, 2009). A less ambiguous teaching about acquisitive economic behavior is found in Luke 17:10, where Jesus explicitly instructs listeners that oikos members should do not be profit-seeking (achreioi).

Jesus elaborates on this theme in the subsequent verses - the celebrated "Lillies of the field" teaching, which point to the folly of conspicuous consumption, materialism and greed-arguing that "life is more than food, and the body more than clothes" (Luke 12:2234). Listeners are told to give away their possessions, and instead to pursue "a treasure in heaven that will never fail, ... for where your treasure is, there your heart will be also.” These verses criticize both an attachment to the trappings of wealth (especially those which signal status) and the deliberate and conscious pursuit of such trappings (see also Luke 16:19-31).

Consider also the Parable of the great feast (Luke 14:15-24), where the first guests who had been invited all reply that they cannot attend, due to specific domestic conventional oikos-related responsibilities: one invitee has just bought a new plot of land, another has invested in five new pairs of oxen, and a third has just married. All three prefer to focus on their immediate material oikos interests, in which they have just made investments (Destro \& Pesce, 2003, p. 230). In this case, the host responds in a counter-cultural (stewardship) manner by inviting people from the margins of society - the poor, the crippled, beggars, and other marginalised people—-so that his oikos may be full for the feast. These guests have nothing to offer; their very low status in society means that even any honor they attribute to the benefactor who is inviting them will not improve the honor status of the host (Neyrey \& Stewart, 2008). Indeed, according to Luke the host is happy (blessed) precisely because they cannot repay him (cf. Luke 14:14; no value capture). 
Finally, when it comes to teachings about chrematistics more generally, it is clear that Luke is particularly concerned about the accumulation of large amounts of wealth (recall that in that time the financial economy was seen to be a fixed pie, where increasing wealth for one oikos meant reduced wealth for others). Of the 18 passages in Luke that deal with money, nine passages mention the word rich, and nine do not. In each of the nine passages that refer to the rich (and thus signal a focus on value capture/acquisitive economics), Luke calls for the redistribution of wealth, typically calling for the rich to sell their possessions and give money to the poor (Dyck, 2013). In contrast, in each of the other nine passages money is seen as a part of everyday life (sustenance economics, or natural chrematistics, in Aristotle's terms).

Taken together, in terms of Figure 1, the passages in this theme deplore practices that emphasize value capture more than value creation, regardless of their level of analysis. This brings us to the final theme and its sub-sections.

\section{Hallmarks of a Universal-Family Organizational From (Oikos)}

Beyond critiquing conventional kinship-based oikos structures and systems, the Central Section also points to an alternative understanding of oikos that is closely associated with the fourth quadrant in Figure 1. In Luke this organizational ideal-type is described using language that suggests that oikoi are to be managed using the same non-conventional approach exemplified by God, denoted as "the kingdom of God." Indeed, virtually all of the examples in Luke of what the kingdom of God look like, and how it can be enacted, take place in an oikos setting (Dyck, 2013). For example, in the only passage where Jesus says "The kingdom of God is like ..." he describes it as being embedded in oikos settings: the kingdom of God is like a farmer who plants a mustard seed in his garden in order to provide a perch for the birds; it is like a baker who adds yeast to her large batch of dough (Luke 13:1821; see also 14:28-33). Note also how both of these descriptions hint at the counter-cultural nature of the kingdom of God: rabbinic tradition forbade the sowing of mustard because it 
was a weed (Oakman, 1986, p. 124), and yeast was seen as a symbol of corruption whereas unleaven stood for what is holy (Longenecker, 2000, p. 141).

Jesus' counter-cultural understanding of oikos is front-and-center in two well-known twin passages in the Central Section, each of which starts with Jesus being asked what people can do to "inherit" a qualitatively different way of life (Luke 10:25-37; 18:18-25). In each passage Jesus is asked by a member of the conventional elite (first a lawyer, then a rich young ruler) what they must do to "inherit eternal life." This phrase is important because the question of inheritance is clearly of interest to people interested in the family firm, and because "eternal life" refers to a new era characterized by the fullness of living that is complete in itself (in the first century, there was no sense that "eternal" life meant "endless" life [Hanson, 1875]). Thus, in these passages members of the social elite are essentially asking about how to belong to the (counter-cultural) oikos of God, and how to achieve a fuller life than they have at the apex of a status quo experience of oikos. In the first passage Jesus tells his listeners to love God, and to love their (non-kin) neighbors as they love themselves. In other words, do not see your neighbor as a potential client to be lorded over (agentic view), but rather as a potential sibling to share with (stewardship/value creation view). This is elaborated upon by the story of the Good Samaritan where a travelling merchant, with no thought of benefitting from it himself, helps a stranger. In the second passage, when a rich ruler explains that he has brought honor to his familial oikos for his entire life, Jesus says: 'Sell all that you own and distribute the money to the poor [a simple form of value creation]' (Luke 18:22), thereby breaking the conventional understanding of what it meant to honor one's kinship oikos. In sum, these two passages describe counter-cultural practices associated with living well according to structures and systems consistent with the kingdom of God, and suggest that these practices are modelled by an altruistic God from whom they are in some way inherited. 
Taken together, the Universal-family oikoi described in Luke can be seen to follow four hallmark principles: (1) include the marginalized; (2) practice benefaction rather than patronage; (3) exemplify servant leadership; and (4) enact salvific organizational practices.

1. Include the Marginalized (e.g., welcome people who do not belong to an oikos). Unlike conventional oikoi, Luke's Jesus repeatedly insists that the resources of the oikos be extended to benefit the most marginalized members of the surrounding society (and especially to the ten percent of the population who currently to do not belong to any oikos). This is evident in the story of the Good Samaritan who helps the literal outcast, and in the story of the householder who invites to his feast "the poor, the crippled, the lame, the blind" from whom he will never receive any form of direct recompense (Luke 14:12-14, see also Destro \& Pesce, 2003, pp. 231-2). It is especially evident in the new model oikos, the cultic community of the kingdom of God, where "people will come from east and west and north and south, and will take their places at the feast in the kingdom of God. Indeed there are those who are last who will be first, and first who will be last" (Luke 13:25-30; see also Luke 14:15-24). The need to move beyond calculative, quid pro quo accumulation of social capital and exchange of favors is made very clearly indeed. Instead, the resources of the oikos are to be used to nurture the marginalized, the outsiders, with no hope or desire for payback.

2. Practice Benefaction rather than Patronage. In terms of relationships with other oikoi, the universal family oikos described in Luke refuses to have clients. Luke repeatedly and explicitly condemns people who pursue their debtors, whilst recommending open-handed (value creating) generosity as an alternative (e.g., Luke 11:5-13). One of the many socioeconomic roles of patron-householders was the provision of financial loans to their clients (Moxnes, 1988, 1991). In an era well before banking, clearly this was a function of no small importance (value creation), but it also served to create ties based on financial inequalities, and potentially provided a (value capturing) vehicle for the rich to eventually seize the assets 
of indebted poor. In Luke Jesus repeatedly presents the forgiveness of debts in a positive light, and the suing of debtors in a very negative one. For example, the Lord's Prayer has the famous line about "forgiving the indebted" (Luke 11:4; the Greek words clearly talk about financial debt) just as God is asked to forgive sins. Similarly, Jesus criticizes a lawyer for burdening the poor with debt, and doing nothing to help those labouring under indebtedness (Luke 11:27-28), and uses the example of someone suing a debtor to show that listeners fail to see the moral faults in their own behavior (Luke 12:57-59). Another well-known example is when the Good Samaritan (Luke 10:25-37) uses his money to help a literal social outcast with no thought of creating indebtedness, an act of benevolence that extended far beyond the stakeholders of his oikos. The parable ends with Jesus saying: "Go and do likewise." A final example is in the Parable of the shrewd manager, which ends with a rich man commending his manager for using oikos resources to decrease the gap between rich and poor (Luke 16:113; for a more detailed analysis of this contested passage, see Dyck et al., 2006). Taken together, these passages describe organizations where resources are used to enhance value creation rather than value capture (e.g., deliberately refuse to exploit others), and where agents act on behalf of the larger community rather than in their own/their principal's financial self-interests.

3. Exemplifying Servant Leadership. Jesus is legendary for servant leadership acts like washing the feet of his disciples and for sayings like:

"The kings of the Gentiles lord it over [kurieuousin, to rule over, dominate] them; and those in authority over them are called benefactors. But not so with you; rather the greatest among you must become like the youngest, and the leader [hegoumenos ${ }^{2}$ like one who serves. For who is greater, the one who is at the table or the one who serves? Is it not the one at the table? But I am among you as one who serves" (Luke 22:25b26).

\footnotetext{
2 "The Greek word choice for leader in this passage (hegoumenos, which appears only in this verse in all of Luke) points to the distinctive feature of the kind of leadership Jesus wants his disciples to aspire to - it is a leadership that deliberately considers the views of others and does not lord it over others." (Dyck, 2013, p. 80)
} 
Consistent with this, the Central Section has several passages that challenge and undermine the conventional social structures and systems regarding how people treat one another within the oikos (e.g., the Parable of the prodigal son, Luke 15:11-32). A particularly relevant passage describes a counter-cultural oikos where the master adopts the role of the lowliest of slaves when he serves oikos members (Luke 12:35-40). By lauding households where leaders freely chose to subordinate their own authority and power to serve the needs of other household members, such passages contrast strongly with conventional norms, and point to a counter-cultural oikos associated with kingdom of God. Jesus describes his disciples as stewards within such a universal family cultic oikos, where everyone, including slaves, are treated with dignity and respect as though they were brothers and sisters (Luke 12:41-48).

4. Enacting Salvific Practices. We believe that the Zaccheaus story is the most noteworthy description in the Central Section of an oikos that embraces salvific organizational structures and systems (Luke 19:1-10). Here we refer to first-century understandings of salvation, which had two meanings. For the Jews salvation meant escaping from oppressive structures and systems, such as living under the thumb of their oppressive Roman overseers. For Greco-Romans, it referred to the bestowal of new blessings, such as new structures and systems that enable positive change (e.g., ironically, they describe the Roman emperor as a Savior thanks to his ushering in Pax Romana) (Powell, 1992).

The story of Zaccheaus describes Jesus entering the oikos of a rich chief tax-collector named Zaccheaus, to the shock of some in Jesus' wider entourage since Jesus is thereby giving social status to someone widely considered to a corrupt outsider. In response:

"Zaccheaus stood there and said to the Lord, 'Look, half of my possessions, Lord, I will give to the poor; and if I have defrauded anyone of anything, I will pay back four times as much.' Then Jesus said to him, 'Today salvation has come to this house [oikos], because he too is a son of Abraham. For the Son of Man came to seek out and to save the lost'." (Luke 19:8-10) 
Much like the shrewd manager (the only other "rich" oikos in Luke that is commended by Jesus), Zacchaeus begins to share his riches to decrease the gap between rich and poor, enacting specific oikos practices that facilitate salvation (money to the poor, redemptive business practices). This is the only passage in Luke where Jesus uses the noun "salvation," thereby drawing further attention to the importance of how goods and services producing organizations are managed. The story describes salvific structures and systems that both reduce oppression associated with the status quo (e.g., Zacchaeus abandons conventional value capture norms) and foster positive change (benefaction and justice extending beyond the stakeholders of the oikos). As in the case of the shrewd manager, Zacchaeus's scattering of resources does not result in the collapse of the focal oikos (i.e., not all the oikos resources are dispersed).

\section{DISCUSSION}

Our analysis indicates that the Gospel of Luke, particularly in its Central Section, has much to say about issues related to the modern idea of family business, especially with regard to agency and stewardship. In particular, our analysis of Luke challenges the romanticized idealistic image of the kinship family business as a timeless example of an inherently exemplary or virtuous organizational form. Luke consistently criticizes organizational forms where authority and wealth are transferred via kinship lines from one generation to the next, which Luke associates with a perpetuation of social inequities. In their place, Luke promotes Universal-family oikoi where everyone is treated as a sister or a brother, with a special invitation for people who previously were excluded from membership in goods and services producing organizations. To be clear, Luke does not reject the idea or downplay the importance of family firms; quite the opposite, Luke sees Universal-family firms as central for instantiating the kingdom of God and salvation. Thus, whilst a halo of goodness is still ascribed to the family firm form, the root cause of this goodness is grounded in only some 
features of the kinship family firm (e.g., caring for other members beyond value-capturing instrumental reasons), and in steadfastly rejecting other features (e.g., refusing to perpetuate power and ownership differences based on kinship).

Our remaining discussion will focus on our study's theoretical contributions and implications for research. In particular, we will: 1) demonstrate that the idea of a Universalfamily firm is observable and credible, and thus merits future study; 2) identify specific implications of our study for the contemporary agency-stewardship literature in family firms; and 3) discuss implications of Universal-family firms for researchers in family business.

\section{Empirical Examples of Universal-Family Firms: Early Church and Contemporary ${ }^{3}$}

The Universal-family firm is not simply an abstract ideal-type relegated to ideas and values promoted in an ancient manuscript. Rather, glimpses of it are apparent in historical as well as contemporary organizations, providing further credibility to this phenomenon and a solid basis for future research and theoretical development (Reay \& Whetton, 2011).

Early Church. Given that our analysis shows that (Luke's) Jesus promoted and modeled a Universal-family oikos, it should not be surprising that his followers in the early Church sought to put this into practice. Hallmarks of the Universal-family oikos are evident from the very beginning of the movement that would become Christianity, which was known for decreasing the gap between rich and poor, practicing inclusiveness beyond kinship groups, sharing economic and material assets, and providing special care for the marginalized and outcasts (e.g., Countryman, 1980; Gotsis \& Drakopoulou Dodd, 2004; Malina, 2001;

Troeltsch, 1931). Early followers are presented as a Universal-family oikos whose members:

"would sell their possessions and goods and distribute the proceeds to all, as any had need. Day by day, as they spent much time together in the temple, they broke bread at home [oikos] and ate their food with glad and generous hearts, praising God and having the goodwill of all the people" (Acts 2:45-47; see also Acts 4:32-34).

\footnotetext{
${ }^{3}$ Our thanks are due to two anonymous reviewers, who proposed that exemplars of "Lucan" family-like organizations be presented.
} 
The reference in this passage to breaking bread together in their oikos refers to sharing communion/eucharist, which was part of everyday meals in the early Church. This practice was widely noted by commentators in that time because it drew attention to the lack of status differentials within the new oikoi of Jesus' followers, in stark contrast to the norms of the day where a master would never eat alongside a slave (note that the etymology of the word company, today often used interchangeably with a business, means literally to share bread together, Hopfl, 2000, p. 316). Acts goes on to describe how this new movement spread from one oikos to another ("house to house;" see Acts 8:3;20:20), as observers are attracted to its distinct practices. Aspects of the Universal-family oikos are also evident in the nascent monastic movement (Gordon, 1989, pp. 10-11, 18), and are especially well-exemplified in the extensive social enterprise provision established in Cappadocian Caesarea by Basil the Great (330-379 AD, see Karayiannis \& Drakopoulou Dodd, 1998, p. 188).

Contemporary examples. Although not very prominent in the business literature, there are nevertheless many glimpses of the Universal-family firm archetype in contemporary practice. Just as in the biblical record, many of these exemplary organizations may not be comprised of people who claim to follow Jesus (e.g., Luke 7:9; 10:37; 19:9). That said, here we will briefly highlight a group of contemporary businesses where the link to gospel teachings are appropriately "transparently observable" (Eisenhardt, 1989), namely the more than 800 firms from 50 countries who belong to the Economy of Communion (EOC) that is part of the Focolare movement within the Catholic church. EOC firms are rooted in principles associate with the Universal-family firm:

"the spirituality of the Focolare stems from the principle that all people are equal members of the one human family - sons and daughters of the one Creator-and therefore have to be treated as brothers and sisters. ... Achieving such relationships, in view of establishing one human family, becomes the main motivating force in every action" (Gold, 2010, p. 128-29; emphases added here). 
EOC firms have found it challenging to apply this family mentality in the public marketplace, for example, when many members of the firm may not be fellow believers; "there are profound challenges to such a system if it is to retain this specific characteristic of intimacy and to operate within the legal, institutional and political framework of the market economy" (Gold, 2010, p. 195). Key practices instituted by owner-managers help to address such challenges, perhaps most notably their voluntary implementation of EOC programs to share firm profits (note the similarity to Zaccheaus's story), which serves to include other members in a universal family even if they have not consciously opted in. The EOC principle of profit-sharing divides a firm's profits into three equal parts: the first is kept to reinvest in the firm, the second is sent to a central EOC-related office where decisions are made about where to redistribute it to poor people around the world, and the third is invested in developing educational endeavors that promote a culture of giving.

Research among EOC firms suggests that, over time, they tend to increasingly: adopt a long-term orientation; engage in participative decision-making; recruit and hire people living on the margins of society; reduce pay differentials within the firm; and create value beyond the financial realm and beyond the borders of the firm's stakeholders (e.g., EOC firms are more likely to internalize externalities by, for example, proactively paying extra costs to enhance environmentally-friendly inputs and practices). They treat even competitors and other non-stakeholders as brothers and sisters (see Gold, 2010, p. 145, and Mundell, 2011, pp. 7-8, for exemplary stories of managers in EOC firms). Gallagher and Buckeye's (2014) analysis suggests that EOC firms enact "structures of grace" and promote business practices aimed at fostering unity — aimed "not at economic efficiency [traditional issues associated with agency theory] or social legitimacy [associated with stewardship issues], or even the inculcation of virtue" - and thus provides an appropriate segue into our next section.

\section{Implications for Stewardship and Agency Research}


Our study makes important contributions to the agency and stewardship literature within family firms, both by focusing attention on the differences portrayed in the four organizational ideal-types depicted in Figure 1, and more generally by introducing the Universal-family firm ideal-type which theories can explain and make predictions about.

Implications arising from the four-fold organizational typology. Our study is consistent with and helps to clarify recent research that suggests that, although stewardship theory and agency theory may appear at be odds, support for both can be found under different circumstances (Le-Breton-Miller et al., 2011). For example, predictions based on agency theories may be more relevant for firms in the left-hand quadrants of Figure 1, and predictions based on stewardship theory more relevant for firms in the two right-hand quadrants. Thus our framework is consistent with the idea that there are (at least) two kinds of kinship family firms, those beholden to agency theory where dominant kinship-centric interests may undermine the firm's financial performance (Agentic family firms), and those consistent with stewardship theory where concern for holistic needs of stakeholders complement a firm's focus on narrow financial performance (Stewardship family firms).

By invoking the ideas of value creation versus value capture, our study provides new concepts for future research in agency versus stewardship theory. The overlap between agency and value capture enables teasing out differences across levels of analysis within agency theory. For example, agency theory predicts that kinship firms generally (quadrants 2 and 3) will enjoy relative advantages compared to Conventional firms (quadrant 1) at the interface between owners and managers (reduced monitoring costs), but at the same time agency theory also predicts that Agentic family firms (quadrant 2) will have relative disadvantages due to their tendency to sub-optimally distribute resources within the firm (e.g., family-based parochialism). The first case uses agency theory to explain why kinship firms efficiently capture value in the marketplace, whereas the second uses agency theory to explain 
why dominant families within kinship firms may capture disproportionate shares of the value created by their firm. The distinction between value capture versus value creation may help to explain why some Stewardship family firms (quadrant 3) are able to avoid the dysfunctional aspects predicted by agency theory associated with Agentic family firms (quadrant 2). This draws helpful attention to the often-looked "principal" in the principal-agent relationship, and leads to the following hypothesis: When principals are more interested in value creation than in value capture, then the negative parochialism predicted by agency theory is overcome. Future researchers can examine a variety of reasons why principals may be more interested in value creation than value capture (e.g., values of founders, economic conditions at founding).

As with the overlap between agency and value capture, the overlap between stewardship and value creation also enables deepened understanding across levels of analysis. For example, future research may use stewardship theory to examine why Universal-family firms focus on creating value at a community-wide level of analysis (e.g., concerns for marginalized people of society), whereas Stewardship family firms focus on creating value among their stakeholders. We expect that such theory development may involve further finetuning of five factors identified in the beginning of our paper that help to explain why family firms are more likely to act like stewards. For example, Stewardship and Universal-family firms may both emphasize valuing relationships, but future research may want to examine whether Universal- (versus Stewardship) family firms tend to place greater emphasis on identity (versus reputation) and a long-term commitment to the larger community (versus a long-term commitment to the firm).

Implications for Universal-family research. In addition to using agency and stewardship theories to explain differences between the four organizational types depicted in Figure 1, we suggest that future agency/stewardship research can also focus more narrowly on the Universal-family firm ideal-type itself. Toward this end, in so far as agency theory is able 
to examine how well the behavior of agents (managers) aligns with the interests of principals (owners), it has much to offer students of Universal-family firms. However, as has been suggested above, the "principals" of Universal-family firms are unlike those considered in traditional agency theory. Rather than have a primary emphasis on maximizing financial wealth, or on preserving the instrumental interests of a particular kinship family, the principals of Universal-family firms are concerned with developing financially-viable goods and service producing organizations that enhance community-wide well-being, and especially the marginalized. This comprises principal's self-interests. The task of agency theory, then, is to explain and predict factors that increase the likelihood that agents will enact such principals' principles. Of course, this can be expected to turn some of the conventional practices associated with agency theory on their head. For example, instead of having principals monitor agents, agency theory might predict that the performance of Universalfamily firm agents will be optimized if agents monitor and become attuned to the needs of the marginalized. In a sense, the Universal-family firm inverts the so-called agency problem: Agents and principals who have firsthand knowledge of their employees and community's needs will be more likely to act on them rather than merely pursue their personal financial interests (consistent with logic of social embeddedness, Le Bretton-Miller et al., 2011). Along the same lines, when applied to Universal-family firms, agency theory might predict improved overlap between the interests of principals and agents when principals see themselves as members of the firms rather than as investors in it.

Similarly, in so far as stewardship theory is able to examine how generous firm members are and how well they serve the larger community (apart from maximizing their own financial performance), it also has much to offer students of Universal-family firms. In particular, our framework draws attention to using stewardship theory to examine Universalfamily firms along two distinct dimensions: 1) their proclivity to share the fruits of their value 
capture (e.g., via philanthropy), and 2) their proclivity to engage in value creation activities that serve the larger community without necessarily optimizing the financial return for the firm (e.g., hiring the marginalized, social entrepreneurship). We would expect relatively high emphasis on value creation activities, which are more counter-cultural and lie closer to the core of the Universal-family firm identity. Stewardship theory may also lead to research to test whether Universal-family firms tend to have a more diverse membership (reflecting the diversity of the community they are embedded in).

Taken together, our analysis suggests that agency theory and stewardship theory may not be in such opposition after all: Universal-family firms provide an occasion for them to be used in complementary ways. Building on a similar observation by Le Breton-Miller and Miller (2009), it may be that their apparent opposition is more a function of the conventional social systems that scholars and practitioners are embedded within, namely the taken-forgranted assumptions that principals' self-interests involve financial wealth maximization and that kinship families are the primary social unit towards achieve self-actualized socioemotional well-being. Indeed, these conventional assumptions are entirely consistent with the materialistic-individualistic "iron cage" that Weber (1958, p. 182) identified more than a century ago, which he suggested could be best escaped via "entirely new prophets" or "the rebirth of old ideas and ideals." We suspect that Weber would have welcomed, and not have been surprised by, our findings that the Gospel of Luke has embedded within it a description of an organizational form that has potential to liberate members (and theories) from the iron cage.

\section{Universal-Family Firms}

Our presentation of Universal-family firms should be of great interest to family business scholars because of how this draws attention to the question of "What is it?" that is being studied (Reay \& Whetton, 2011, p. 105). In particular, we ask: "What is family business 
beyond biological kinship relationships?" The distinction between Universal-family firms versus kinship family firms (and/or Conventional firms) invites and compels family business scholars to examine hallmarks of family-ness beyond biological relations. This is no easy task, but tackling it promises to bear fruit in terms of richer conceptual and theory development in the literature. Note that such reconstruction of the meaning of familynamely, for it to have more of a sociological than a biological meaning —is entirely consistent with the changing meaning of family in society at large (e.g., blended families, homosexual marriage and parenting, and so on) (Braithwaite et al., 2010; Marcianna \& Sussman, 1991). In addition to identifying some implications of the Universal-family firm for researchers in family business (e.g., need to go beyond biological definitions, implications for stewardship and agency theory), our paper also addresses each of the other four components associated with developing a theoretical contribution to family business research (Reay \& Whetton, 2011, p. 107). In particular, our paper demonstrates that the idea of a Universalfamily firm is observable and credible (e.g., evident in descriptions of practices associated within the first century Early Church and the twenty-first century Economy of Communion movement), and describes key factors associated with Universal-family firms and how these factors are related to each other (inclusivity of the marginalized, benefaction that counters patron-client relations, servant leadership that treats everyone with dignity, and embracement of liberating organizational practices). Finally, in terms of identifying possible antecedents and conditions associated with Universal-family firms — which may range from the personal beliefs and practices of organizational members, to structural characteristics of who comprises an organization, to what variety of capitalism a firm is operating in —we suggest that Universal-family firms are more likely to be evident when: members are open to the idea of an altruistic God (consistent with the "theological turn", Simmons, 2008); members practice spiritual disciplines (Dyck, 2014); firms are not dominated by one biological family (Le 
Breton-Miller, Miller \& Lester, 2011, p. 717); managers do not serve (only) one biological family (Miller et al., 2014); and firms operate in a coordinated rather than a liberal market economy (Carnevale \& Mazzuca, 2014).

Finally, beyond its conceptual and theoretical contributions, our focus on Universalfamily firms is also important for practical reasons. For example, because of their unique emphasis on community-wide value creation, Universal-family firms may provide greater benefits to society-at-large than kinship family firms. Indeed, the key themes found in Luke with regards to Universal-family firms have a timely and timeless quality to them. The themes of sustenance economics, decreasing the gap between rich and poor, and treating everyone with dignity are entirely relevant in our world of Occupy Wall Street and its concerns regarding social justice, sweat shops, and the negative effects that result when financial wellbeing out-trumps all other forms of well-being (e.g., ecological, spiritual, social, physical, psychological, etc.). Luke's implicit hypothesis is that the Universal-family firm would optimize value creation and community-wide stewardship, and minimize negative aspects associated with an over-emphasis on (financial) value capture and the financially selfinterested assumptions associated with agency theory.

\section{Conclusion}

Our study has demonstrated the merit in analyzing historical texts in their socioeconomic context and drawing insights for contemporary family business research. We encourage other scholars to use similar methods to contribute to theory-development. In particular, our study of the Gospel of Luke provides welcome opportunities for contemporary scholars to (re)consider the socio-psychological core of what constitutes the hallmarks of a family business. Rather than define family firms in biological kinship terms, a focus on Universal-family firms draws attention to sociological and psychological characteristics. This seems a richer and more promising vein of theoretical and empirical research, and permits 
researchers who wish to study firms that exhibit attributes such as those described in Luke to escape from the hand-cuffs of familial kinship. Of course, this liberation may also be offputting to some, because it threatens the biological core identity of the family business research, and also de-emphasizes the mainstream interest in value capture and profit maximization. But if the theory and research related to family firms cannot stand on its own without a biological kinship connection and a primary focus on financial well-being, then perhaps cutting the umbilical cord is long overdue. 


\section{REFERENCES}

Anderson, R. C., \& Reeb, D. (2003). Founding-family ownership and firm performance: Evidence from the S\&P 500. Journal of Finance, 58(2), 1301-1328.

André, R. (2012). Assessing the accountability of the Benefit Corporation: Will this new gray sector organization enhance Corporate Social Responsibility? Journal of Business Ethics, 110(1), 133-150.

Aristotle, Politics (translated by Benjamin Jowett). Kitchener, ON: Batoche Books. Found Dec. 28, 2009 at http://socserv2.mcmaster.ca/ econ/ugcm/3113/aristotle/Politics.pdf. Aristotle (2006). Nicomachean ethics, translated by W.D. Ross (2006) eBooks@ Adelaide. Aronoff, C. E. \& Ward, J. L. (1995). Family-owned businesses: A thing of the past or a model for the future? Family Business Review, 8(2), 121-130.

Baergen, R. A. (2006). Servant, manager or slave? Reading the parable of the rich man and his steward (Luke 16.1) through the lens of ancient slavery. Studies in Religion/Sciences Religieuses, 35(1), 25-38.

Barney, J. B., \& Hesterly, W. (1999). Organizational economics: Understanding the relationship between organizations and economic analysis. In S. R. Clegg, C. Hardy, T. B. Lawrence, and W. R. Nord (Eds.) The SAGE Handbook of Organization Studies (2 ${ }^{\text {nd }}$ edition) (pp. 111-148). London: SAGE Publications.

Battiliana, J., Lee, M., Walker, J., \& Dorsey, C. (2012). In search of the hybrid ideal. Stanford Social Innovation Review 10(3), 50-55.

Berger, P.L., \& Luckmann, T. (1967). The social construction of reality. New York: Doubleday.

Bertrand, M., \& Schoar, A. (2006). The role of family in family firms. Journal of Economic Perspectives, 20, 73-96.

Blodgett, M., Dumas, C. \& Zanzi, A. (2011). Emerging trends in global ethics: A comparative study of U.S. and international family business values. Journal of Business Ethics, 99, 
29-38.

Bowen, M. (1978). Family therapy in clinical practice. New York: Jason Aronson.

Bourdieu, P. (1986). The forms of capital. In J.G. Richardson (Ed.) Handbook of Theory and Research for the Sociology of Education (pp. 241-258). Westport, CT: Greenwood Press.

Braithwaite, D. O., Bach, B. W., Baxter, L. A., DiVerniero, R., Hammonds, J. R., Hosek, A. M., Willer, E.K., \& Wolf, B. M. (2010). Constructing family: A typology of voluntary kin. Journal of Social and Personal Relationships, 27(3), 388-407.

Buber, M. (1958). I and Thou. New York: Scribner.

Carnevale, C. \& Mazzuca, M. (2014). Sustainability reporting and Varieties of Capitalism. Sustainable Development, (22), 361-376.

Colli, A. (2012). Contextualizing performances of family firms: The perspective of business history. Family Business Review, 25(3), 243-257.

Corbetta, G., \& Salvato, C. (2004). Self-serving or self-actualizing? Models of man and agency costs in different types of family firms: A commentary on "Comparing the agency costs of family and non-family firms: Conceptual issues and exploratory evidence”. Entrepreneurship: Theory \& Practice, 28(4), 355-362.

Countryman, L. W. (1980). The rich Christian in the Church of the early Empire: Contradictions and accommodations. Lewiston, NY: E. Mellen Press.

Davis, G. F. (2013). After the corporation. Politics \& Society 41(2), 283-308.

Davis, J. H., Schoorman, R., \& Donaldson, L. (1997). Toward a stewardship theory of management. Academy of Management Review, 22(1), 20-47.

Demsetz, H. (1983). Structure of ownership and the theory of the firm, Journal of Law \& Economics, 26, 375-390.

Destro, A., \& Pesce, M. (2003). Father and householder $n$ the Jesus movement: The 
perspective of the Gospel of Luke. Biblical Interpretation, 11(2), 211-238.

Dierksmeier, C. \& Pirson, M. (2009). Oikonomia versus chrematistike: Learning from Aristotle about the future orientation of business management. Journal of Business Ethics, 88, 417-439.

Donaldson, L. (1990). The ethereal hand: Organizational economics and management theory. Academy of Management Review 15(3), 369-381.

Dodd, S. D., \& Gotsis, G. (2009). 'Enterprise values' in the New Testament and antecedent works. International Journal of Entrepreneurship and Innovation, 10(2), 101-110.

Dyck, B. (2013). Management and the Gospel: Luke's radical message for the first and twenty-first centuries. New York: Palgrave-Macmillan.

Dyck, B. (2014). God on Management: The world's five largest religions, the 'theological turn', and organizational and management theory and practice. Research in the Sociology of Organizations, 41, 23-62.

Dyck, B., \& Neubert, M. (2010). Management: Current practices and new directions. Boston MA: Cengage/Houghton Mifflin.

Dyck, B., Starke, F. A. \& Dueck, C. (2006). Just what was Jesus saying? Two interpretations of the parable of the shrewd manager. Journal of Biblical Integration in Business, Fall, 111-140.

Dyck, B., Starke, F. A., \& Dueck, C. (2009). Management, prophets and self-fulfilling prophecies. Journal of Management Inquiry, 18(3), 184-196.

Eddleston, K., Kellermanns, F. W., \& Sarathy, R. (2012). Resource configuration in family firms: Linking resources, strategic planning and technological opportunities to performance. Journal of Management Studies, 45(1), 26-50.

Eisenhardt, K.M. (1989). Building theory from case research. Academy of Management Review, 14, 532-550. 
Elliott, J. H. (1991). Temple versus household in Luke-Acts: A contrast in social institutions. In J. H. Neyrey (ed.), The social world of Luke-Acts: Models for interpretation (pp. 211-240). Peabody, MA: Hendrickson Publishers.

Esler, P.F. (2000). The Mediterranean context of early Christianity. In Esler, P.F. (Ed.) The early Christian World, vol.1-2 (pp. 3-25). London: Routledge.

Gaffney, R.J. (2012). Hype and hostility for hybrid companies: A fourth sector case study. Journal of Business, Entrepreneurship \& the Law, 5(2), 329-345.

Galbraith, J.K. (1987). A history of economics: The past as the present. London: Penguin. Gallagher, J., \& Buckeye, J. (2014). Structures of grace: The business practices of the Economy of Communion. Hyde Park, NY: New City Press.

Gates, B. (2007). Remarks of Bill Gates: Harvard commencement. http://news.harvard.edu/ gazette/story/2007/06/remarks-of-bill-gates-harvard-commencement-2007/

Gold, L. (2010). New financial horizons: The emergence of an economy of communion. Hyde Park, NY: New City Press.

Gomez-Mejia, L. R., Takács Haynes, K., Nuñez-Nickel, M., Jacobson, K. J. L., \& MoyanoFuentes, J. (2007). Socioemotional wealth and business risks in family-controlled firms: Evidence from Spanish olive oil mills. Administrative Science Quarterly, 52, 106-137. Goodrich, J.K. (2010). Paul, the oikonomos of God: Paul's apostolic metaphor in 1 Corinthians and its Graeco-Roman context. Doctoral thesis, Durham University. Available at Durham E-Theses Online: http://etheses.dur.ac.uk/299/.

Gordon, B. (1989). The problem of scarcity and the Christian Greek Fathers: John Chrysostom and some contemporaries. Studia Patristica, 21, 102-120.

Gotsis, G. \& Drakopoulou Dodd, S. (2004). The economic thought of St. James and The Jerusalem Love Community. History of Economic Ideas, 12(1), 1-35.

Gupta, V., \& Levenburg, N. (2010). A thematic analysis of cultural variations in family 
businesses: The CASE project. Family Business Review, 23(2), 155-169.

Hanson, J. W. (1875). The Greek word aion-aionios translated everlasting-eternal in the Holy Bible, shown to denote limited duration. Chicago, IL: Northwestern Universalist Publishing.

Hanson, K. C. \& Oakman. D. E. (1998). Palestine in the time of Jesus: Social structures and social conflicts. Minneapolis, MN: Fortress Press.

Haugh, H., \& McKee, L. (2003). 'It's just like a family'--shared values in the family firm. Work \& Family, 6(2), 141-158.

Hauswald, H., \& Hack, A. (2013). Impact of family control/influence on stakeholders' perceptions of benevolence. Family Business Review, 26(4), 356-373.

Hopfl, H. M. (2000). Ordered passions: Commitment and hierarchy in the organizational ideas of the Jesuit founders. Management Learning, 31(3), 313-329.

James, H. (2006). Family capitalism. Cambridge, MA: Belknap-Harvard University Press.

Jensen, M. C. \& Meckling, W. H. (1976). Theory of the firm: managerial behavior, agency costs and ownership structure. Journal of Financial Economics, 3, 305-60.

Karayiannis, A. (1992). Entrepreneurship in classical Greek literature. The South African Journal of Economics, 60(1), 67-93.

Karayiannis, A. \& Drakopoulou Dodd, S. (1998). The Greek Christian Fathers. In Lowry S.T., \& Gordon, B. (Eds.), Ancient and Medieval Economic Ideas and Concepts of Social Justice (pp. 163-208). Leiden: EJ Brill.

Kim, Y. H., Yu, R., Kulik, S. P., Shih, Y., \& Scully, M. O. (2000). Delayed 'choice’ quantum eraser. Physical Review Letters, 84(1), 1-5.

Kloppenborg, J. S. (2006). Associations in the ancient world. In A. J. Levine, D.C. Allison Jr., \& J. D. Crossan (Eds.), The historical Jesus in context (pp. 232-338). Princeton, NJ: Princeton University Press. 
Le Breton-Miller, I., \& Miller, D. (2009). Agency vs. stewardship in public family firms: A social embeddedness reconciliation. Entrepreneurship Theory and Practice, 33(6), 1169-1191.

Le Breton-Miller, I., Miller, D., \& Lester, R. H. (2011). Stewardship or agency? A social embeddedness reconciliation of conduct and performance in public family businesses. Organization Science, 22(3), 704-721.

Longenecker, R. N. (2000). Luke's parables of the Kingdom. In R. N. Longenecker (Ed.), The challenge of Jesus' parables (pp. 125-147). Grand Rapids, MI: Eerdmans.

Lubatkin, M.H., Durand, R., \& Ling, Y. (2007). The missing lens in family firm governance theory: A self-other typology of parental altruism. Journal of Business Research, 60(10), 1022-1029.

Lungeanu, R., \& Ward, J. L. (2012). A governance-based typology of family foundations: The effect of generation stage and governance structure on family philanthropic activities. Family Business Review, 25(4), 409-424.

Malina, B.J., \& Neyrey, J.H. (1991). First century personality: Dyadic, not individual. In J.H. Neyrey (Ed.) The Social World of Luke-Acts: Models for Interpretation (pp. 25-65). Peabody, Massachusetts: Hendrickson Publishers.

Malina, B.J. (2001). The Social Gospel of Jesus. The kingdom of God in Mediterranean perspective. Minneapolis, MN: Fortress Press.

Malina, B. J. \& Rohrbaugh. R. (2003). Social-science commentary on the synoptic Gospels. Minneapolis, MN: Fortress Press.

Madison, K, Holt, D, Kellermanns, K and Ranft, A (2016) Viewing Family Firm Behavior and Governance Through the Lens of Agency and Stewardship Theories, Family Business Review, March 2016, 1-16

Margolis, J., \& Walsh, J. P. (2003). Misery loves company: Rethinking social initiatives by 
business. Administrative Science Quarterly, 48, 268-305.

Marshall, I. H. (1978). Commentary on Luke. The New International Greek Testament Commentary. Exeter: Paternoster Press.

Metzger, B. M., \& Murphy, R. E. (Eds.). (1991). The new Oxford annotated Bible with the Apocryphal/Deuterocanonical books: New Revised Standard Version. Oxford: Oxford University Press.

Miller, D., \& Le Breton-Miller, I. (2006). Family governance and firm performance: Agency, stewardship, and capabilities. Family Business Review, 19, 73-87.

Miller, D., Breton- Miller, L., Minichilli, A., Corbetta, G., \& Pittino, D. (2014). When do non-family CEOs outperform in family firms? Agency and behavioural agency perspectives. Journal of Management Studies, 51(4), 547-572.

Mitchell, R. K., Agle, B. R., Chrisman, J. J., \& Spence, L. J. (2011). Toward a theory of stakeholder salience in family firms. Business Ethics Quarterly, 21(2), 235-255.

Morck, R., \& Yeung, B. (2003). Agency problems in large family business groups. Entrepreneurship Theory and Practice, 27(4), 367-382.

Morck, R. K., Percy, M., Tian, G. Y., \& Yeung, B. (2005). The rise and fall of the widely held firm: A history of corporate ownership in Canada. In R. Morck (Ed.) A history of corporate governance around the world: Family business groups to professional managers (pp. 65-140). Chicago: University of Chicago Press.

Moxnes, H. (1988). The economy of the kingdom: Social conflict and economic relations in Luke’s Gospel. Philadelphia: Fortress Press.

Moxnes, H. (1991). Patron-client relations and the new community in Luke-Acts. In J.H. Neyrey (Ed.) The Social World of Luke-Acts (pp 241-268). Peabody, Mass: Hendrickson Publishers, Inc. 
Mundell, J.A. (2011). The Economy of Communion business and Corporate Social Responsibility. The Economy of Communion and the African Economic Vocation - Theory and

Best Practice. Catholic University of Eastern Africa, Nairobi, Kenya, January 26- 28.

Nagle, B. D. (2006). The household as the foundation of Aristotle's Polis. Cambridge, UK: Cambridge University Press.

Neyrey, J. H. \& Stewart E. C. (Eds.) (2008). The social world of the New Testament: Insights and models. Peabody, Mass: Hendrickson Publishers.

Oakman, D. E. (1986). Jesus and the economic questions of his day. Lewiston, NY: The Edwin Mellen Press.

Payne, G. T., Brigham, K., Broberg, J. C., Moss, T. W., \& Short, J. C. (2011). Organizational virtue orientation and family firms. Business Ethics Quarterly, 21(2), 257-85.

Poggi, G. (1965). A main theme of contemporary sociological analysis: Its achievements and limitations. British Journal of Sociology, 16(4), 283-294.

Polanyi, K. (1944). The great transformation: The political and economic origins of our time. Boston, MA: Beacon Press.

Porter, M.E. (1980). Competitive strategy. New York, NY: The Free Press.

Powell, M.A. (1992). Salvation in Luke-Acts. Word \& World, 12(1), 5-12.

Rawson, B. (Ed.) (2011). A companion to families in the Greek and Roman worlds. Oxford: Wiley-Blackwell.

Reay, T. \& Whetten, D. A. (2011). What constitutes a theoretical contribution in family business? Family Business Review, 24(2),105-110.

Reed, J. L. (2007). The HarperCollins visual guide to the New Testament: What archeology reveals about the first Christians. New York, NY: Harper Collins.

Saller, R. P., \& Shaw, B. D. (1984). Tombstones and Roman family relations in the Principate: civilians, soldiers, and slaves. Journal of Roman Studies, 74, 124-156. 
Santos, F. M. (2012). A positive theory of social entrepreneurship. Journal of Business Ethics, $111,355-351$.

Schulze, W. S., Lubatkin, M. H., \& Dino, R. (2003). Exploring the agency consequences of ownership dispersion among the directors of private family firms. Academy of Management Journal, 46(2), 179-194.

Sharma, P., Chrisman, J. J., \& Gersick, K. E. (2012). 25 Years of family business review: Reflections on the past and perspectives for the future. Family Business Review, 25, 5-15.

Shleifer, A., \& Vishny, R.W. (1997). A survey of corporate governance. Journal of Finance, 52, 737-783.

Simmons, J.A. (2008). God in recent French phenomenology. Philosophy Compass, 3(5), 910-932.

Sirmon, D. G., \& Hitt, M. A. (2003). Managing resources: Linking unique resources, management, and wealth creation in family firms. Entrepreneurship Theory and Practice, 27(4), 339-358.

Troeltsch, E. (1931). The social teaching of the Christian churches. New York: Macmillan.

Vallejo, M. C. (2008). Is the culture of family firms really different? A value-based model for its survival through generations. Journal of Business Ethics, 81(2), 261-279.

Von Kimakowitz, E., Pirson, M., Spitzeck, H., Dierksmeier, C., \& Amann, W. (Eds.) (2010). Humanistic Management in practice. London: Palgrave Macmillan.

Wade-Benzoni, K.A. (2002). A Golden Rule over time: Reciprocity in intergenerational allocation decisions. The Academy of Management Journal, 45(5), 1011-1028.

Ward, J. L. (2004). Perpetuating the family business: 50 lessons learned from long lasting, successful families in business. Marietta, GA: Family Enterprise Publishers.

Weber, M. (1958). The Protestant ethic and the spirit of capitalism (trans. T. Parsons). New York, NY: Scribner's. 
Wiseman, R., \& Gomez-Mejia, L. R. (1998). A behavioral model of managerial risk taking. Academy of Management Review, 23(1), 133-153.

Figure 1: Four organizational ideal types

Non-kinship Firms

Relative emphasis 